\title{
RESPONSIBILITY FOR PROVIDING FALSE INFORMATION IN CONNECTION WITH PROVISION OF DETECTIVE SERVICES
}

\author{
IWONA SZYMCZAK \\ University of Szczecin, Faculty of Management and Economics of Services, POLAND \\ e-mail: iwona.szymczak@usz.edu.pl
}

RECEIVED

ACCEPTED

JEL

CLASSIFICATION

KEYWORDS

ABSTRACT
10 December 2018

28 December 2018

$\mathrm{K} 12$

personal interest, detective services, liability, due diligence

The detective service consists of obtaining and providing the information about persons, objects and events. For evaluation of quality of this kind of economic activity the basic criterion is true information. This article deals with the issue of the detective liability for providing false information during providing a detective service. It could be both the contractual liability as well as the tort liability. The main goals of this research is pointing out what kinds of damages may occur in the connection with the detective activity. Since one of the main duties of a detective is providing the true information, the detailed goal of this research is an explanation in what way false information may cause damage and what is the connection between false information and infringement personal interests, which are a private life, a honor, family ties (marital ties). In this paper the attention is drawn to the cases in which a personal interest is violated. They are torts, for which the detective may be sued not only by the person who is a party of detective service contract, but as well as by any person suffered from damages arising as the result of false information. The detailed goal for considerations relates to the issue of pointing out a professional standard of detective due diligence and legal premises of detective liability for damage arising from his negligent action, in particular from false information providing by him, and answer to the question how the detective can be released from this liability. For that it is necessary to introduce a pattern of reasonable detective and principles of proper performing detective services. They shape the standards of due diligence for a detective. The method used is analysis a legal regulations, juridical-cases and doctrine view in order to set out conclusion for future legislation.

\section{Introduction}

The Act on Detective Services (called later: ADS) regulates the branch of economic activity called Private Police. Detective activity is a specific type of economic activity relating to the penetration of a private life. In details, the contract on detective services covers activities consisting of obtaining, processing and transferring information about persons, objects and events. Because the main purpose of the detective service is to obtain and provide the 
information about persons, objects and events (Kudła, Pawlik, 2018, p. 104), thus, there is a very high level of risk of the violation of the right to privacy, which is a fundamental human right. Therefore the legislator did not grant special powers to detectives to facilitate their services, but on the contrary strengthened legal measures to protect the right to privacy. The basic duty for professionals of detective service is to provide true information.

The Act on Detective Service indicates providing false information as the cause for occurring a damage. The person who may suffer from damages arising in connection with providing the false information is not only the person who commissioned detective service but as well as the person who is traced by the detective. Notwithstanding that is a contractual liability of entrepreneur under the Civil Code (art. 471 Civil Code, called later: CC), the Act on Detective Services sets out a tort liability, which is mentioned in art. 14 ADS as to a legal ground for the liability of a detective and art. 23c ADS as a legal ground for the liability of an entrepreneur. The main goal of this article is to explain how regulations mentioned above modified the civil liability arising from providing detective service, in respect to the Civil Code rules. Moreover, it will be examined what scope of damages caused by providing false information may be and who takes the civil liability for it.

\section{The entities responsible for providing false information and the extent of theip liability}

In this point I am going to present options for configuration of subjects who may claim before the court for damages arising from false information in connection with a detective service. In other words: who may sue and who may be sued for it. First of all, false information may be treated as improper performance of contract on detective service. As it was mentioned above, the main purpose of detective activity is to obtain and to provide information. An entrepreneur and commissioner are the parties of contract on detective service. Since the major object of this contract is providing information, so the entrepreneur is obliged to provide true information. His liability is based on civil code rules (art. $471 \mathrm{CC}$ ). The entrepreneur takes responsibility for it regardless of who did operational act. The contractual liability charges only the entrepreneur, although the operational action causing damage was done by the detective. The entrepreneur takes 'vicarious liability' against person who is a party of contract (Article 474 CC). Next, the entrepreneur may have a refund claim against his employee or his sub-contractor (Brylak, 2016, p. 114).

Under the contractual liability only the commissioner is protected. He is a receiver of the false information, however beyond contractual liability there are persons who are investigated by a detective. The false information could affect this person who is not a party of contract (called a third party). Moreover, this person is unaware of being traced. Although the scope information to be investigated by the detective is wide, the main goal of his activity is to reveal the hidden information. The most wanted are personal data, especially the sensitive information. A detective has no duty to get permission to receiving and forwarding these information (art. 25a (4) ADS in the connection with art. 25 and art. 32-35 Personally Identifiable Information Protection Act). A traced person cannot correct these data which will be provided to the commissioner, so the crucial issue is to provide the true information.

Therefore contractual liability of an entrepreneur for no-performance or improper performance arising from art. $471 \mathrm{CC}$ is too narrow to reward damages to an aggrieved person, so the legislator sets out, simultaneously with the contractual liability, the tort liability. Responsibility for the tort arising from false information charges the detective (Article 14 ADS) and the entrepreneur (art. 23c ADS). Each of them can be directly sued by the aggrieved person who does not have to be a party to the contract on detective service.

Gozdór thinks similarly pointing to art. $429 \mathrm{CC}$ as the basis of liability for the false information. He explains that despite the fact that the detective is employed by an entrepreneur, he is not a person directly subject to the 
entrepreneur's instructions. Hence, his tort liability is not transferred to an entrepreneur and art. $430 \mathrm{CC}$ is not applied (Gozdór, 2006, p. 110). The detective who is an employee or a subcontractor of the entrepreneur under civil contract may be directly sued before the court for a tort under the art. 14 ADS. The claimant may be a commissioner or other person who is not bound by the contract on detective service. Article 14 ADS covers direct civil liability of a detective as the person taking operational action, regardless of whether he is an entrepreneur or a subcontractor (who is mentioned in art. $747 \mathrm{CC}$ ). Under the art. 14 ADS a detective, as a certificated professionals, takes direct liability for damages caused while performing the activities referred to in art. 2 (1) ADS, and as a result of providing false information, according to the rules set out in the Civil Code. It seems that the aforementioned article 14 ADS modified rules of Civil Code in this way that the detective takes direct responsibility for full damages arising as consequences of providing false information regardless of the scope of his liability against his employer.

\section{False information as legal cause of occurring damages}

Art. 14 ADS and art. 23c ADS indicates false information as legal cause occurring damages. These are special regulations which are the exception to the general principle according to which satisfaction of claims for indirect damages for third parties are denied (Stecki, 1990, p. 290). The limitation of liability to direct damage, i.e. to the first aggrieved party, is justified by the danger of flooding with claims by third parties. So this view is accepted that the indirect damage may be satisfied only if it is allowed in the statutory law (e.g. art. 446 CC). The indirect damage appears when the causative action or omission is connected with another event or with the extraordinary features of the person and the things that consequently lead to the damage (Stecki, 1990, p. 289). The risk from to high amount of claim may be limited by demonstrating the absence of an adequate causal relationship, which is very likely in the case of multi-elements sequences of events (Lackoroński. 2007, p. 151). The indirect damage may be satisfied if there is an adequate connection between it and the primary event causing it, which is called causa proxima (Kaliński, 2014b, p. 320).

The legislator indicates providing the false information as an initial event which may lead through the sequences of events or omission to the damage. The third person's harm is a result of series of events which are connected with providing the false information to the commissioner. The commissioner who receives false information is an intermediate chain and he may spread this information or keep it. The significance in art. 14 ADS (like art. 23c ADS) is that, it indicates the false information as a causa proxima, which is the active, efficient cause that sets in motion a chain of events bringing about a result, without the intervention of any force, beginning and working actively from a new and independent source.

\section{Kindls of damages which may arise from providing false information}

As to the kinds of damages for which a detective is liable, the provision art. 14 ADS refers to rules of civil code. So it should be explained what kind of damages caused by providing false information may be considered in the detective activity (similar remarks will refers to art. 23c ADS). In the civil law there are two kinds of damages. These are: the property damage and non-property damage. First one is an economic loss which decreases value of assets (damage in property). The second one is a personal harm. There are two subcategories of economic losses. First one is the damage which includes the losses incurred like expenses, costs. Second subcategory is a damage including the benefits which the person could have obtained if the event had not happened. For calculating the amount of the first subcategory of damages the difference between the value of assets before the event causing 
damage and the value of assets after this event had happened is needed. The term used sometimes for this kind of damage is 'out of pocket'. The second category covers potential earning or other benefit which would belong to assets if the event had not happened. As an example is the false information about finance state of company, which entails in making the wrong decision on financial investment, which causing loss of potential profits.

As to the non-material damage, it is the negative experience (pain, trauma) and feelings of the injured person (victim). Not all non-material damage is compensated in our law, but only these which are pointed out in statutory law. One of them is the harm which is a consequence of the personal interest violation (Kaliński, 2014a, p. 100).

The personal interest, especially that which could be violated by the detective who provide false information, is: a honor, a good name or a private life. In this cases non-material damage is called harm. A consequence violating the personal interest shall be a damage. Moreover, in science, there is a view that just entering the sphere of the rights of another person is a violation of personal interest, which recognized as doing damage (Kaliński, 2014a, p. 101). Of course, not every piece of false information causes an infringement of personal interest, but only that which covers a serious allegation.

For example, as we consider a defamation, which is one of cases treated as violation of personal interest, it is necessary to prove that false information affects a negative self-evaluation of an injured person (Wierciński, 2002, p. 10). The aggrieved person may suffer from the stress pain, grief, disappointment as result of false information being defamation.

Other cases of violation of personal interest could be destruction of family ties. In doctrine the value of family life is recognized as one of the types of personal interest entering a wider scope of private life (Pazdan, 2007, p. 1143). For example, the person who is being followed by the detective, may sue him before the court for false evidence of his marital infidelity, which led to divorce which causes both finance damages and harm (Kosińska, 2012, p. 667).

In this case there are two type of claims. They are: a non-finance claim and a finance claim. The non-finance claim is included in art. $24 \S 1 \mathrm{CC}$. An injured person may demand from a person committing the infringement to perform the actions, which are necessary to remove negative effects, in particular that the person makes a declaration of the appropriate form and substance. The second type is finance claim. There are two kind of finance claims. The first is a claim of money indemnification for suffering a harm. According to the terms provided in the Civil Code, an aggrieved person may demand money compensation for himself or to a specific public purpose. The detective may be sued for making harm, which is breaking of the marital bond or loss of trust of the spouse. Under the art. 14 ADS, in the court proceedings, the aggrieved person may, in easier way, prove the direct connection between false information and an infringement of personal interest. In other words, in order to prove occurrence of damage it is not necessary to prove a full sequence of consecutive events which ultimately lead to the occurrence of damage. There is a view that to support claims of harm compensation, it is enough to prove a violation of personal interest. It is not necessary to supply an evidence to prove the damage occurs. The indemnification should be paid if there has been a violation of the personal interest (Barta, Markiewicz, 2005, p. 792). Although it is difficult to fix an appropriate amount of money as compensation for such harm, which is not adequate to an economic value, however the court may award a cash payment having regard to: the degree of violation, its severity and duration of suffering (Cygan, 2012, p. 364). See more deatails: justification of High Court judgment from 19.11.2008, III CSK 171/08, Lex 584204). 
As to the second kind of damage, the detective may be also sued for a proprietary-damage arising in the connection with a harm. It could be an expenditure for medical treatment, pills, injections, etc. In a divorce case, the finance damages could cover a loss of living standards. Other examples of the liability of the detective for economic losses caused by the false information refer to business relations, payment capabilities or credibility in these relationships (Patryk, 2017, p. 155). Under the influence of false information the businessman may take wrong decisions as to a future contract or its omission.

\section{The legal prerequilisites of detective's liability}

In this point I will discuss the legal prerequisites of the civil liability of a detective for tort arising as the result of the untrue information. Therefore the most court cases refers to infringement the personal interest, so I focus, mainly on art. $24 \mathrm{CC}$. It covers a legal presumption of illegality of violation. It means that, if a person, who made such a violation, wants to avoid the responsibility, he should prove that his act was legal. Otherwise, if he fails he will be charged with a liability. In the doctrine two separate premises are distinguished. One of them is an illegal action of a perpetrator, but the second one is that his conduct was negligent.

For supporting a non-finance claim is enough that a perpetrator's behavior was illegal. In order to release from it, he shall point out a special statutory provisions which allow on entrance in area of a personal interest of this person or consent of aggrieved person. Otherwise a perpetrator is obliged to fulfill a non-finance claims. For finance claims, there is necessary to prove one more circumstance which is a perpetrator's guilt (Machnikowski, 2016, p. 64). The doctrine accepts the view that a careful conduct (due diligence) of a perpetrator releases him from finance liability. So that, the detective as the defendant should prove a due diligence what means that the burden of proof is put on him in order to release him from a liability (Barta, Markiewicz, 2005, p. 795). In the situation in which he fails in evidence for his innocence, he will be charged with responsibility. If the action was illegal, but he acted with a diligent care, he may be released only from his finance liability. He should prove that he acted carefully, with due diligence and reliability. This is accepted by the case law (see judgment of High Court of 14.05.2003, I CKN 463/01, OSP 2004/2/22, judgment of High Court of 5.03.2002, I CKN 535/00, www. orzecznictwo.sn.sites/ orzcznictwo/orzeczenia.pl) The key issue is what a professional standard shall be applied to the detective activity. I start from the professional standard which is set up for a detective in the Act on Detective Service. It includes the rules which shape the pattern of due diligence for the detective. According to art. 6 ADS, the detective should, when performing the activities, be guided by the principles of ethics and loyalty to the person ordering the service and with a special care not to violate the freedoms and rights of people and citizens.

While, according to the art. 11 ADS, the detective who wants to avoid responsibilities while performing detective services is obliged to:

a) obey the law and refuse to perform an illegal or unethical act;

b) exercise due diligence and reliability, and especially check the truthfulness of the information obtained.

Both abovementioned provisions shapes a pattern of due diligence in detective activities.

\section{Professional standard in verification of untrue information}

The defense of the detective may consist of presentation of evidence that he acted with due diligence in collection of information and verified them. The more serious allegation is the more professional diligence it should be (Wierciński, 2002, p. 137). Untrue information is false or poor quality information (e.g. quotes with cut out pieces 
are treated as false information (Barta, Markiewicz, 2005, p. 792). Moreover, the detective may be commissioned to make a verification of information. As an example I give an insurance activity in which there is a risk of insurance fraud. Thus, when the insurer suspects that this type of crime has been committed (insurance fraud) he commissions investigation of the event which caused a damage in order to know, whether an event was faked or not (Patryk, 2017, p. 160).

The detective is obliged to follow the professional standard which is more severe than for other professions. The similar standard is demanded from the journalists, who can be treated on the same level of the risk connecting with false information. The parallel is in obtaining information, however the differences regards a purpose to which it is used. In press activity the aim is delivering of information to the public (unlimited group of people), but in detective activity the detective has the commission to obtain information which will be used by the client who undertakes the actions against the person to whom this information refers to.

At the stage of collection and providing information, the victim is not able to prevent its consequences, because he does not know about action taking against him. Thus the standard of the diligence shall be strict. Such a conclusion come out from art. 25a ADS with connection with art. 25 and art. 32-35 Personally Identifiable Information Protection Act, which releases the detective from the obligation to obtain consent for the processing of personal data of the investigated person. The detective's duty is a research of all potential available sources. Cutting or omitting some information may result in false information (Wierciński, 2002, s. 153). Unreliable sources of information shall be verified. The reliable information is total, information which is precise and accurate. The detective should avoid biased facts and skipping of some of them that can lead to erroneous findings as to the course of real events (Wierciński, 2002, pp. 152-153).

The standard of due diligence for verification of information is also influenced by its status (source, from which information is retrieved. (Barta, Markiewicz, 2005, p. 799). Official information or data on entities, which was derived from the public source like the Nation Court Register or Land Register are covered by the special legal presumption on truth, reliance and trust. The detective may rely on credibility of the data included in the public register. As to information which is a circumstantial evidence, that is based only on indirect traces, it may be used it although a detective needs to act with a special precaution when providing such information (Barta, Markiewicz, 2005, p. 800).

The review of the court cases shows that the injured person is protected both in the case in which there is not enough evidence to support the statement that the allegation was true, as well in case when there is not enough evidence to prove the contrary statement, which is that 'the allegation was false'. Such a view is confirmed by the court judgment which states: Although the result of proceeding doesn't entail certainty that it was defamation or not, although there is no enough evidence to support any of both contrary statements, however the perpetrator may be charged with making the declaration that there is no basis for spreading of the message (Judgment of Appealing Court in Krakow from 16.09.1993, I ACz 406/93. quoted from: Barta, Markiewicz, 2005, p. 794).

\section{Conclusions}

In detective service, false information could be a cause of wide scope of damages. In the Act on Detective Services, it is mentioned twice (in art. 14 ADS and art. 23c ADS). It is a causa proxima of damage which could appear in connection with a detective service.

It seems that the legislator has undoubtedly strengthened the position of the aggrieved party, who can assert claims from both the entrepreneur and the detective, regardless he is an employee or subcontractor. Under Polish 
law there is no special rules for liability of detectives for damages arising in connection with their professional activity, but legislator put stress on quality of that service which consists of providing true information. Firstly, the legislator provides suggestion for legal interpretation that there is a direct connection between false information and economic damages or harm of people which are the object of operational action of a detective. In the court proceedings the victim may proves in easier way that infringement of personal interest is a result of false information, because it is not necessary to prove a full sequence of consecutive events which ultimately lead to the occurrence of damage.

The secondly, the legislator pointed out that the detective as the person who is directly liable for damages caused while performing his operational activities and as a result of providing false information. It is tort liability which consists in misconduct of the detective causing damages as result of providing false information. An injured person may be a commissioner or other person not being a party of contract on detective service.

\section{References}

Barta, J., Markiewicz R. (2005). Bezprawność naruszenia dobra osobistego wobec rozpowszechniania w prasie nieprawdziwych informacji. In: L. Ogiegła, W. Popiołek, M. Szpunar (eds.), Rozprawy prawnicze. Księga pamiątkowa M. Pazdana (pp. 791-803). Kraków: Uniwersytet Śląski

Brylak, J. (2016). Ustawa o usługach detektywistycznych. Komentarz. Warszawa: C.H. Beck.

Cygan, K. (2012). Sposoby ustalenia zadośćuczynienia pieniężnego za naruszenie dóbr osobistych w świetle aktualnego Orzecznictwa Sądu Najwyższego. In: R. Sztychmiler, J. Krzywkowska (eds.), Problemy z sądową ochroną praw człowieka (pp. 361-369). Olsztyn: Uniwersytet Warmińsko-Mazurski.

Gozdór, G. (2006). Usługi detektywistyczne. Warszawa: C.H. Beck.

Kaliński, M. (2014a). Odpowiedzialność odszkodowawcza. In: A. Olejniczak (ed.), System Prawa Prywatnego, t. 6, Prawo zobowiazzań - część ogólna (pp. 1-214). Warszawa: C.H. Beck.

Kaliński, M. (2014b). Szkoda na mieniu i jej naprawienie. Warszawa: C.H. Beck.

Kosińska, J. (2012). Sprawy rozwodowe a usługi detektywistyczne. In: R. Sztychmiler, J. Krzywkowska (eds.), Problemy z sądową ochroną praw człowieka (pp. 461-464). Olsztyn: Uniwersytet Warmińsko-Mazurski.

Kudła, J., Pawlik, R. (2018). Wykonywanie usług detektywistycznych z użyciem środków technicznych umożliwiających uzyskiwanie w sposób niejawny informacji i dowodów. Prokuratura i Prawo, 4, 102-119.

Lackoroński, B. (2007). Odpowiedzialność za szkody pośrednie w polskim prawie cywilnym. In: J. Jastrzębski (ed.), Odpowiedzialność odszkodowawcza (pp. 148-158). Warszawa: C.H. Beck.

Machnikowski, P. (2016). Komentarz do art. 23 oraz art. 24 k.c. In: E. Gniewek, P. Machnikowski (ed.), Kodeks cywilny. Komentarz (pp. 58-65). Warszawa: C.H. Beck.

Patryk, J. (2017). Współpraca biur detektywistycznych z zakładami ubezpieczeń w walce z oszustwami i wyłudzeniami ubezpieczeń komunikacyjnych. In: K. Pujer (ed.), Problemy nauk prawnych, t. 2, (pp. 155-165). Wrocław: Exante.

Pazdan, M. (2007). Dobra osobiste i ich ochrona. In: A. Olejniczak (ed.), System Prawa Prywatnego, t. 1. Prawo cywilne - część ogólna (pp. 58-65). Warszawa: C.H. Beck.

Stecki, L. (1990). Problematyka odpowiedzialności za szkodę pośrednią. In: S. Sołtysiński (ed.), Problemy kodyfikacji prawa cywilnego (pp. 287-303). Poznań. Uniwersytet Adama Mickiewicza.

Wierciński, J. (2002). Niemajątkowa ochrona czci. Warszawa: C.F. Muller.

www.orzecznictwo.sn.sites/orzcznictwo/orzeczenia.pl.

Civil Code called later: CC.

The Act on Detective Services - called later: ADS.

Cite this article aS: Szymczak, I. (2018). Responsibility for providing false information in connection with provision of detective services. European Journal of Service Management, 4 (28/2), 485-491. DOI: 10.18276/ejsm.2018.28/2-58. 